\title{
An overview of the historical and technical evolution of Azerbaijan timber architecture
}

\author{
Mahmoud Ouria ${ }^{1}$, H. Cetin Turkcu ${ }^{2}$ \\ ${ }^{1}$ Postgraduate Student of Architecture, Near East University, Nicosia-Cyprus \\ ${ }^{2}$ Faculty of Architecture, Dokuz Eylul University, Izmir-Turkey \\ Email address: \\ Ouria@Email.com (M. Ouria), cetin.turkcu@deu.edu.tr (H. C. Turkcu)
}

To cite this article:

Mahmoud Ouria, H. Cetin Turkcu. An Overview of the Historical and Technical Evolution of Azerbaijan Timber Architecture. Science Research. Vol. 2, No. 2, 2014, pp. 13-20. doi: 10.11648/j.sr.20140202.11

\begin{abstract}
This paper investigates construction systems of historical buildings in Azerbaijan-Iran by comparing and classifying their architectural elements in detail. Mithrava Mosque in Binab-city and Forty-Column Palace in Qazvin-city are presented as case studies that illustrate Azerbaijan timber architectural traits according to its style. The plans, sections and other technical data have been presented for evaluation of Azerbaijan timber constructions as an architectural style according to their special factors. The plans and all details of exemplary figures are presented based on field survey after controlling all the mentioned plans that are documented in heritage and cultural organization of eastern Azerbaijan in I.R Iran. There is a historical review of Azerbaijan timber architecture extending to 3000 years ago, covering Urartian, Maday and Safavid dynasties before attending to the technical details of construction methods in this paper. Then, important construction elements are analyzed in detail by their plans and sections that are documented on field survey.
\end{abstract}

Keywords: APDANA, Historical Evolution, Azerbaijani Architecture, Timber Construction, Historical Technique

\section{Introduction}

East Azerbaijan district is located in north-west of Iran and its cultural heritages had been affected by different tribes such as; Summerians, Urartians, Maydians, Persians, Safavids and Qajars. It should be mentioned that all tribes had a special and also achieved architectural method but it is obvious they did follow same construction systems since 3000 years ago[1].

Because of Azerbaijan's location among immense forests, wooden/timber materials were prevalent in their constructions. Subsequently, constructing the first "APADANA" with wooden material and timber structure was an accessible method by Urartians in the 1 st millennium B.C. [2].

Apadana is a palace hall with wooden columns or pillars that masonry walls surrounded its arenas to increase the stability. This type of construction system was commonplace among working-class people especially in rural parts of Azerbaijan that was an original pattern for Persian architecture. Azerbaijan timber architecture has developed during 31 centuries. There are a lot of buildings that constructed during 17 th century when the Safavid Dynasty was flourishing as well.
Safavid kingdom is one of the bright eras in Azerbaijan architectural styles. There are a lot of mosques and belvederes that have been built in that time [3]. Maraga-city and Binab-city are two important cities in Azerbaijan history that include many mosques.

For example; we can mention of Aq(white)Mosque in Maraga City, Zövüsht Maraga in Maraga Citty, Blue Mosque in Maraga City, Gogan Mosque in Gogan City, Meydan Mosque in Binab City, Shir-Ali Building in Ajabsher, Ismayi-bay House in Maraga City[4]. Also, there are a lot of belvederes that are constructed as a summerhouse where kings were settling there temporary. The belvederes of Qazvin city and Dash Maki cities are the oldest and important ones but it should be mentioned that Azerbaijan timber architecture did not limited to just Azerbaijan district. For example; Isfahan city was third capital city of Safavid Kingdom which located outside of Azerbaijan district in modern Iran borders.

However, modernism hegemony did treat against classical and traditional arts but Azeri architecture could preserve its own originality and environmental compatibility at least in religious buildings in the 19th century during when the Qajar dynasty was loosing its independency by the western colonists [5]. 


\section{History and Tradition of Timber Architecture in Iran}

Obviously, researching about timber architecture in Iran without paying attention to Azerbaijan timber architecture is impossible because timber architecture expressed by Azerbaijan building for the first time. Then, regional architecture in other parts of Iran was affected by these constructional methods.

\subsection{History of Timber Architecture in Azerbaijan}

Timber architecture of Azerbaijan is developed during a long history from Urartian civilization to Safavid kingdom. Urartians invented a special method to cover palaces by wooden columns that is called APADANA [6].

This type of architecture allowed architects to design broad arenas. Urartian architecture systems compounded wood with stone but it replaced by wood and brick in latest years of Safavid dynasty because heat storage capability of brick was more compatible in frozen climate of Azerbaijan to solve energy problem [7]. There are some special techniques joining lateral load-bearing elements with the vertical members.

\subsubsection{Urartian Timber Architecture}

As it is mentioned, the first buildings of Azerbaijan timber architecture are established in Urartian era when the first palaces covered with wooden columns that called APADA (Figure1) [8]. Apadans have a flat roof and its internal space was divided in small arenas because it provided to construct broad covered spaces in ancient eras especially before inventing timber systems.

Floor area of an Apadana in Altin-tepe is about $(44 \mathrm{~m} * 25,3 \mathrm{~m})$. Stone is main material of basements, floors and walls of this Apadana. Thickness of its wall is $3 \mathrm{~m}$. Its iterance(bu kelime ne?) is located in east aspect. It has 18 $(3 * 6)$ wooden columns those provide its stability. Its cylindrical wooden column shafts were rested on stone bases with $1.5 \mathrm{~m}$ diameter. Natural ventilation and lighting of internal spaces were provided by vents located on the roof surface (Figure1).

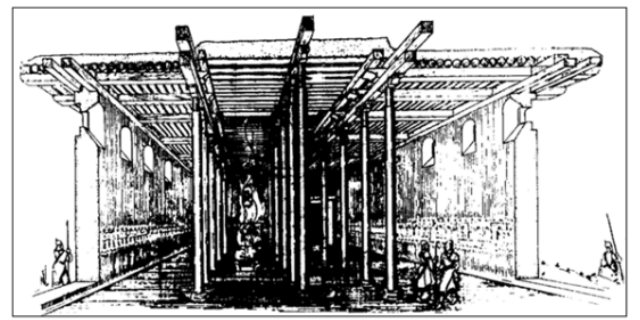

Figure1. Apadana in Altin-tepe (Firuzi, B, 1976)

It should not be forgotten that timber systems did not implemented just for covering internal spaces because there are some special buildings that their external spaces constructed by timber systems. For example, Armavir in bank of Araz river had been constructed timber architecture. It has an external space that is closed from three aspects (Figure2) [9].

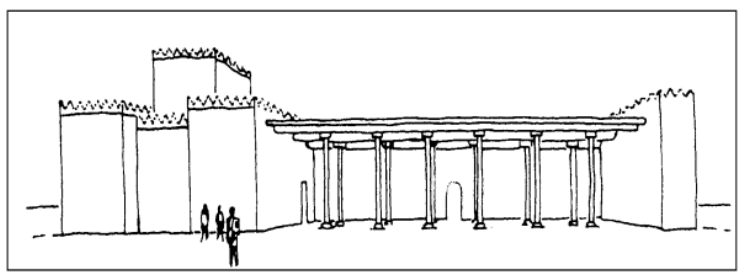

Figure 2. Armavir bank of Araz river (Dyson, M, 1989)

There were some especial methods that cover roofs in Urartian timber architecture that implemented cross beams in two or three layers to diffusion of force distribution that comes from roof loads as well. They implemented three beams side-by-side in the lowest layer to reinforce its structure (Figure3).

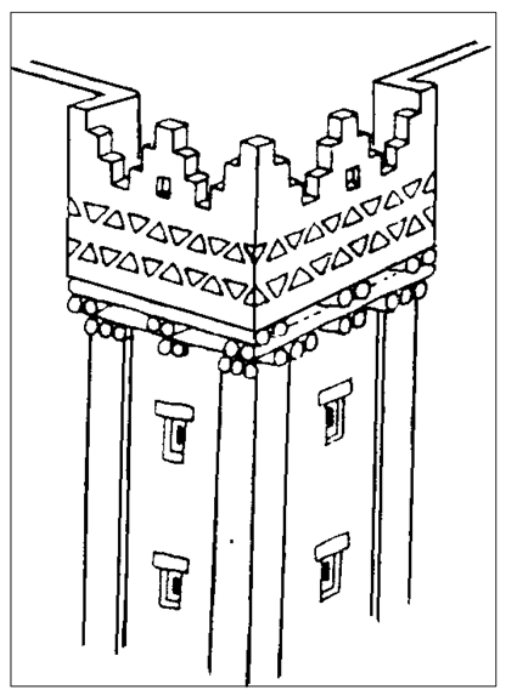

Figure 3. Urartian Timber Structure (Volfram,K, 1976)

\subsubsection{Maday Timber Architecture}

Maday timber architecture appears like Uratian timber architecture but it was a little more compatible with its environmental conditions. Buildings height were shorter than Urartians, columns were rested on stone stages rather than on single bases. There had been some typical buildings in Maday empire, made of timber construction that included of wooden verandas like internal systems (Figure4) [10].

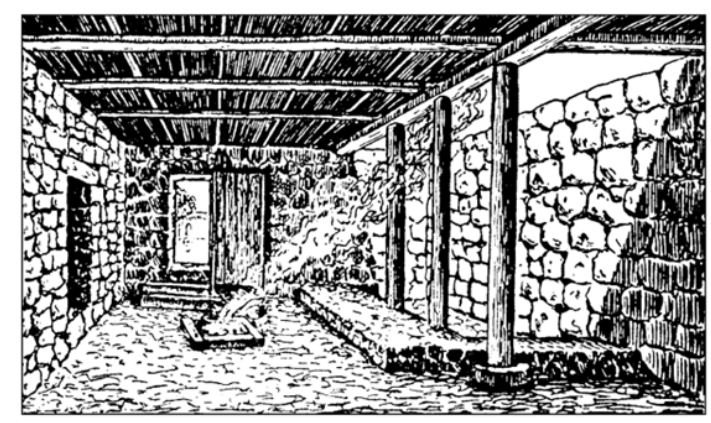

Figure 4. Maday Timber Structure (Diachonova, E,M, 1976) 


\subsubsection{Safavid Timber Architectur}

Safavid timber architecture is an improved version of prior dynasties that involved during a long history. As quantitative aspect, this period is one of the most bright eras in Azerbaijan art history because a lot of wooden buildings with timber structure are constructed in that time[11]. Also, type of joints, shafts and bases of columns were not simple as before. There are several buildings that are constructed during Safavid dynasty in Azerbaijan that it is impossible to consider all of them here, but some of them are presented in the examples. Names of the presented examples are as follows; Aq (white)Mosque in Maraga City, Zövüsht Maraga in Maraga Citty, Blue Mosque in Maraga City, Gogan Mosque in Gogan City, Meydan Mosque in Binab City, Shir-Ali Building in Ajabsher City, Ismayi bay House in Maraga City, Dar-al-Seltenet in Maki City, Shah Abbas Palace(40 sutun) in Qazvin City[12].

\subsection{Constructional Elements of Azerbaijan Timber Structures}

As mentioned in the prior chapters, Azerbaijan timber architecture has three bright eras affected by three powerful empires. The buildings in any special period have some distinctive factors that differs than other era but they have some clear structure that allows us to consider them as an evolved style during different periods of Azerbaijan's art history. There are some specific features in this kind of buildings that make them distinctive than other buildings as follow;

a) Implementing wooden material in the lateral elements and middle columns.

b) Constructing load bearing walls with red-brick

c) Rectangular plans

d) Stone bases with mortar

\subsubsection{Foundations in Azerbaijan Timber Architecture}

There are two types of foundations implemented in Azerbaijani timber buildings. In the first method that is related to the prior eras, plinth stone with lime mortar had used in lower part of walls. Combined stones with mortar implemented under-ground as the main part of foundation. Also, the part of foundation that located under ground and above the main part of it filled by compacted soil to strengthen (Figure5).

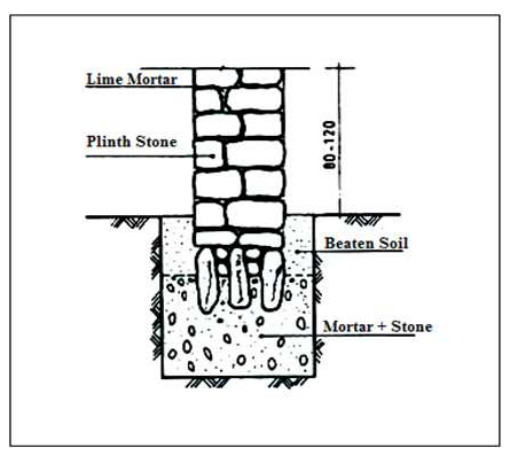

Figure 5. Mortar-Stone Foundation.
On the other hand, there was a special type of construction of foundations in Azerbaijan district that was combined of rubble-stones and wood. In this method, wood plays the major role. Wooden elements are implemented for two purposes. Firstly, vertical element reacts against compressive forces that surrounded by stones. Secondly, the horizontal element is implemented to react against tensional forces.

\subsubsection{Walls in Azerbaijan Timber Architecture}

There are two type of walls in Azerbaijan timber architecture that are considered in this research; internal and external walls. It should not be forgotten that the external walls of Azerbaijan timber architecture are considered in two separate parts. Firstly, it includes the walls that divide internal spaces from externals boundaries. Secondly, side walls that define privacy boundary. In other word, these type of wall only separate two external spaces.

\subsubsection{Internal Walls in Azerbaijan Timber Architecture}

Internal walls operate like partitions but they are load-bearing elements too. Brick with mortar is the main material of walls. Bricks with dimension 22/10/6.5 cm are used in these type of walls. Internal walls include of white plaster or color where expose of prayers. Other view of internal walls where is located in passage or "dalans" lacks plaster but has raked-joints. (Figure 6,7).

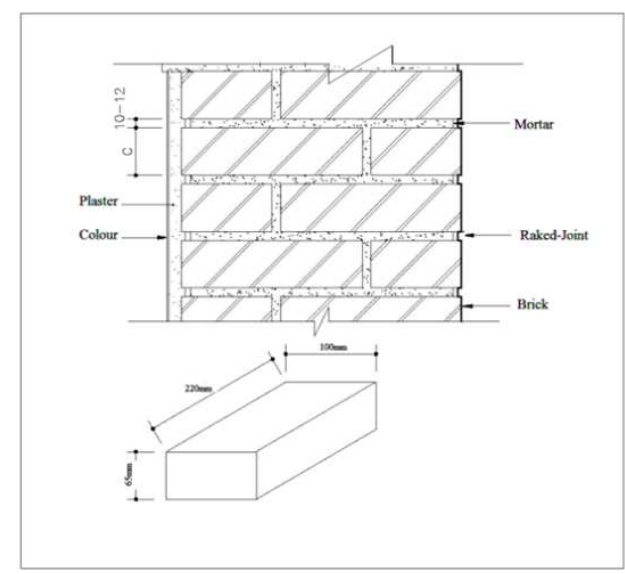

Figure 6. Internal brick wall (Ouria, M, 2013)

On the other hand, the walls that implemented to separate side spaces are categorized among external walls. In these walls, both view of wall is created by cut-stones and middle part of walls is filled with random-rubble stones. It should not be forgotten that raked-joints are used in these kind of external walls.

\subsubsection{External Walls in Azerbaijan Timber Architecture}

There are two types of external walls in this topic. Firstly, walls that divide internal space from external space. In this kind of walls, plaster or color was implemented on internal side but flat-stone with wire holders and moist-counter stone implemented in the lower part of wall protecting it against moist (Figure7). 


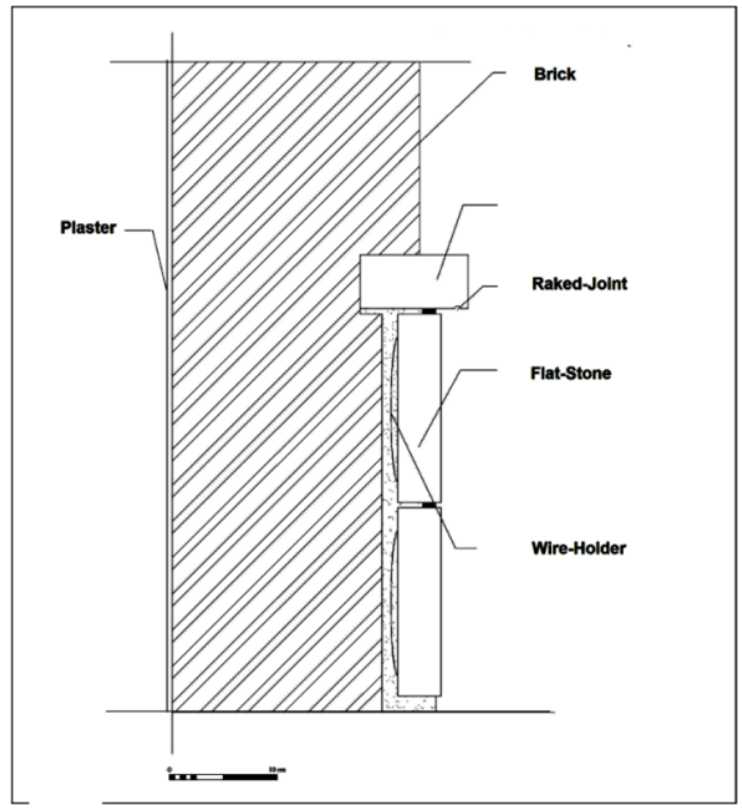

Figure 7. External wall I (Zakhiri, M, 2011)

\subsubsection{Columns in Azerbaijan Timber Architecture}

Whereas main material of columns is timber, that produced of Tabrizi trees. Generally, the columns are circular and hexagonal in crosssection. Implemented columns in these buildings include three major parts, namely; base, shaft and capital(Figure8).

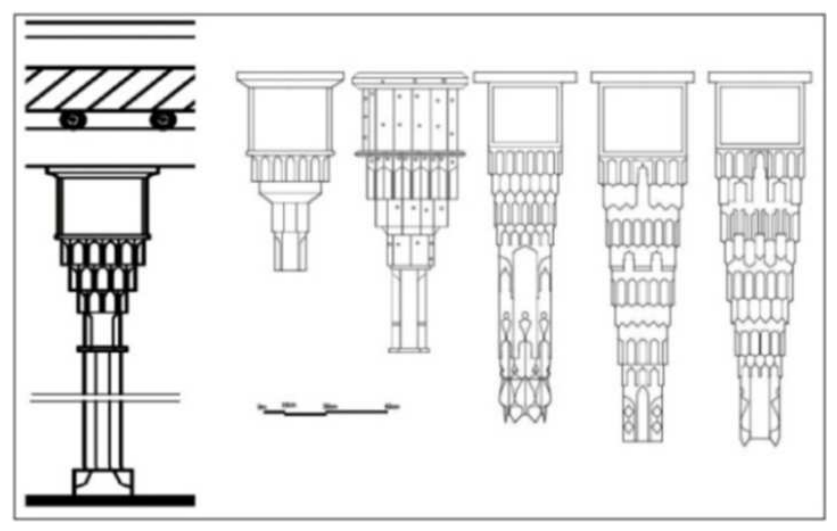

Figure 8. Column Detail (Ouria, M, 2013)

\subsubsection{Base of Columns in Azerbaijan Timber Architecture}

The column's bases of these buildings are built up of two shapes; polygonal and rectangular shapes. Also, they are built up with stone material to fortify building stability. Average height of them is approximately $25 \mathrm{~cm}$. There are two types of joints to connect the shaft into base of columns; Mortise-and-tenon joint, flat joint(figure9).

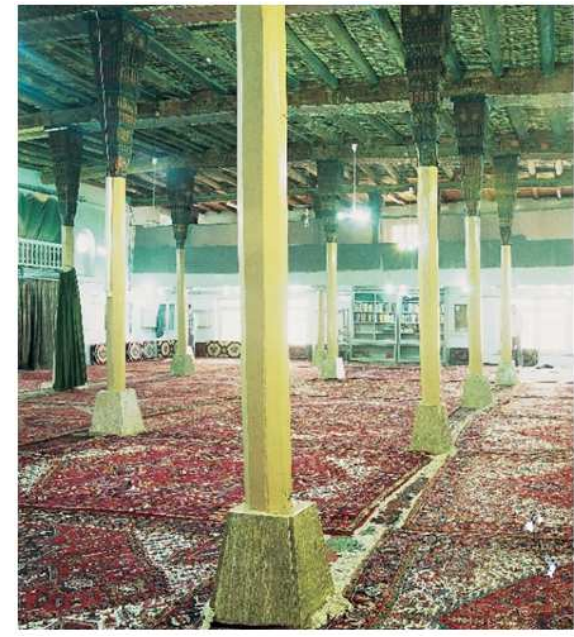

Figure 9. Stone Base of Aq Mosque (Haddadi, R, 1388)

\subsubsection{Base of Columns in Azerbaijan Timber Architecture}

The column's shaft is major element of column. It is made up with wood in circular and polygonal cross sections but it should not be forgotten that there are also some rectangular shape of shafts in Sahand-Azerbaijan wooden architecture especially around Urmia-Lake1. Generally, there is a special part in top of the capitals that is called MÜQERNES. All of the capitals have a solid body that has a direct relation with their height (Figure8).

\subsubsection{Capitals of Columns in Azerbaijan Timber Architecture}

The capitals of columns in timber architecture of Azerbaijan have built up with a special method that is called as Müqərnəs in Azəri Language. It is made of Tebrizi woods that is common in the region. Usually they are designed in rectangular shape but circular capitals can be found though rarely. The capitals have three main part; its flat is located under rectangular wooden beam that has the broadest part of capital distributing roof-load. Conic part of capital include some Islamic forms that are maintaining structural coherence. A rectangular or circular wooden part is located in the lower part of capital that divides the capital from the shaft(Figure10).

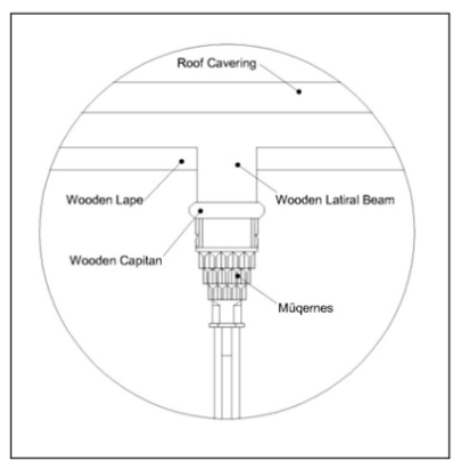

Figure 10. Capitals detail of columns in timber architecture of Azerbaijan (Ouria, M, 2013) 


\subsubsection{Roof and Ceiling Details of Azerbaijan Timber Architecture}

According to the mentioned detail in the (Figure11,12) wooden beams are located beside each other in a short distance that varies between $40-60 \mathrm{~cm}$. Main beams are joined to rafter beams by iron nails. Then, the roof is covered with $30-60 \mathrm{~cm}$ thatch and it is fixed by a layer of mortar before tiling the roof. It should be mentioned that the natural tar was prevalent in north-western part of Iran and especially in the Azerbaijan. So, it was usual to use natural tar instead of tiles. At last, ceilings are covered with cotton covers that include some Islamic paints as adoration (Figure11,12).

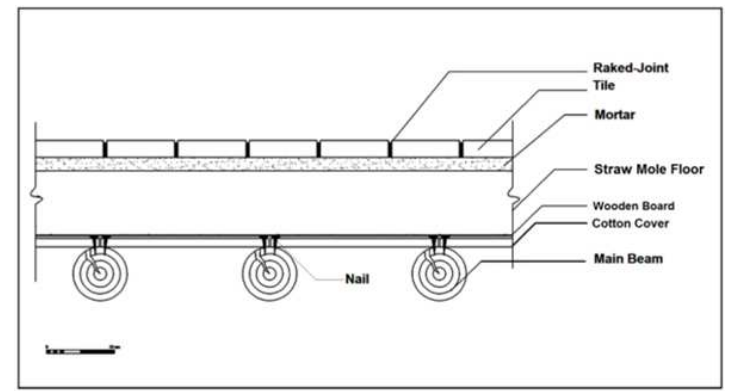

Figure 11. Roof detail in timber architecture of East-Azerbaijan (Ouria, M, 2013)

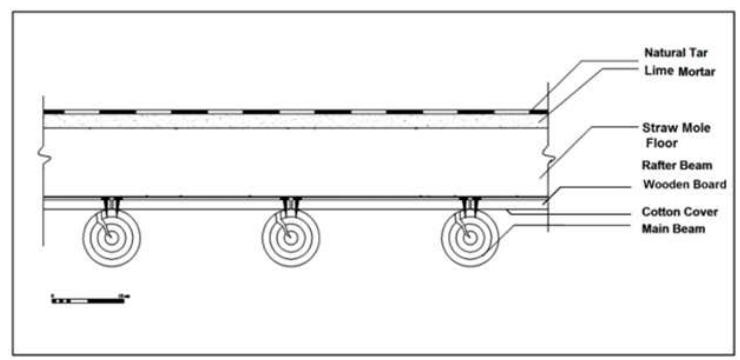

Figure 12. Roof detail with tar isolation in timber architecture of East-Azerbaijan (Ouria, M, 2013)

In the case of ground floors, ceiling superposed on wooden beams that is located into load-bearing brick walls. There was no need of nails to install lateral element on wooden beams because they are fixed to wall by lime cement (Figure13). Also the ceiling is supported on middle walls continuously (Figure14).

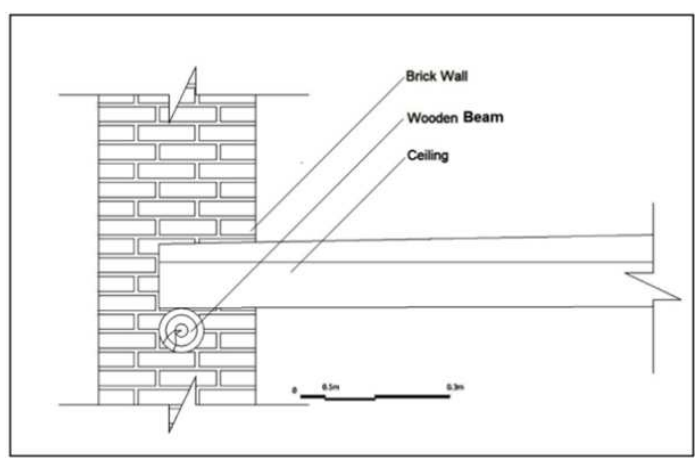

Figure 13. Ceiling joining with around wall in timber architecture of East-Azerbaijan (Ouria, M, 2013)

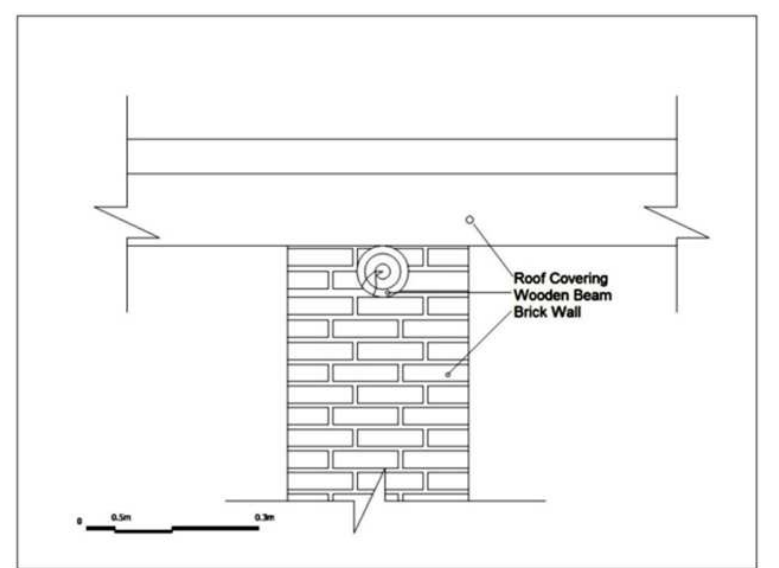

Figure 14. Ceiling joining with middle wall in timber architecture of East-Azerbaijan (Ouria, M, 2013)

There is a 40-60 $\mathrm{cm}$ high parapet around the roof. Cement arms sre used beside the parapet and under the natural tar to preserve isolation against cracking. Brick sorts has been drafted separately to be distinguished as much as possible (Figure15).

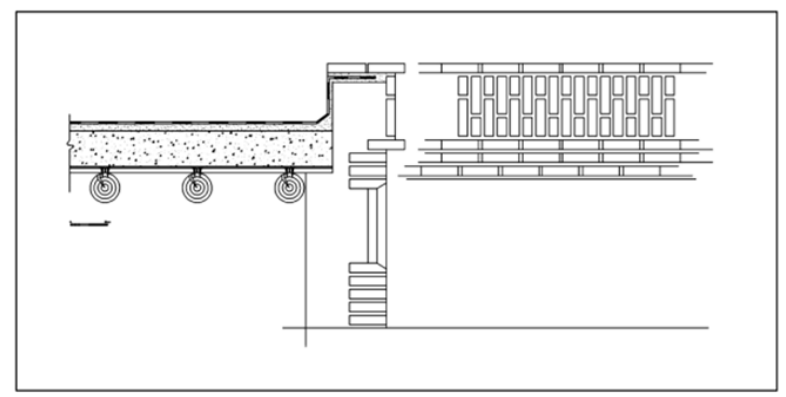

Figure 15. Roof detail with tar isolation in timber architecture of East-Azerbaijan (Ouria, M, 2013)

\section{Examples of Azerbaijan Timber Architecture}

All the surveyed plans, sections, elevations and column parts of every single building are presented in this chapter separately.

\subsection{Mithrava Mosque in Binab-City of Eastern Azerbaijan}

This mosque is located in the most important part of Binab whose name is Mehrabad neighborhood. According to historical events relevant to the Mithra and Zoroaster, and their inalienable part of the Azerbaijan territory is clear. Mitra associated with Mehrabad but on how their relation may not be discussed without concrete evidence and artifacts.(Bu cümle anlaşılmıyor. Seninle konuşalım)

According to the inscription on the mosque, it has been built on 951 AD during the reign of Shah Tahmasp. The main prayer hall of the mosque is rectangular with dimensions $19,6 \times 18,6$ meters. Totally, it has 36 wooden columns. They have polygonal cross section. The height of 
columns is 4,75 meters. Capitals include mogharnas decorations (Figure16,17).

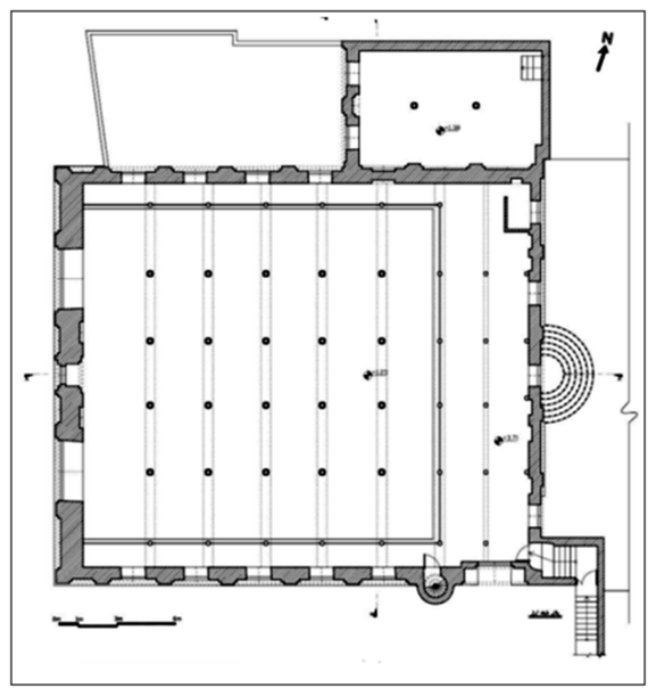

Figure 16. Ground Floor Plan of Mehrabad mosque in Binab city (Ablullahi, MR, 2008)

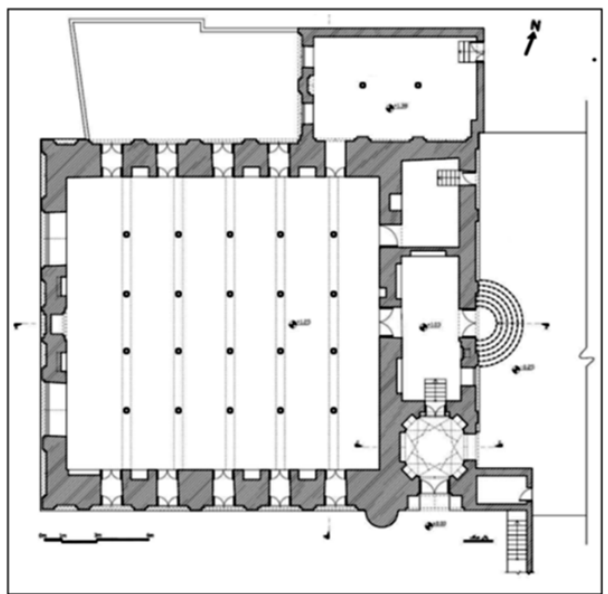

Figure 17. Plan of Mehrabad mosque in Binab city (Ablullahi, MR, 2008)

Generally, it has five type of capitals according their mogharnases (Figure18,19). Arabesques and Khatayi motifs used to cover the ark of the beams. Side yard of the mosque is located in the northern part of the main nave like portico with 4 meters width but the eastern and western sections of the mosque have ivans with $1 / 1 \mathrm{~m}$ width. The mosque has 15 windows with $1,2 \mathrm{~m}$ width and 1,75 height. Mehrabad mosque includes a minaret with blue tiles that accrued to original structure during Qajar dynasty.

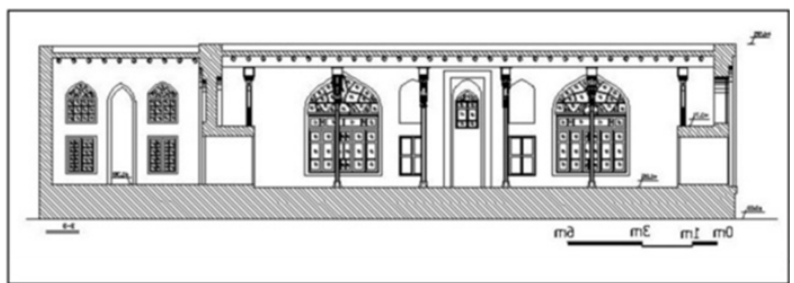

Figure 18. Section of Mehrabad mosque in Binab city (Ablullahi, MR, 2008)

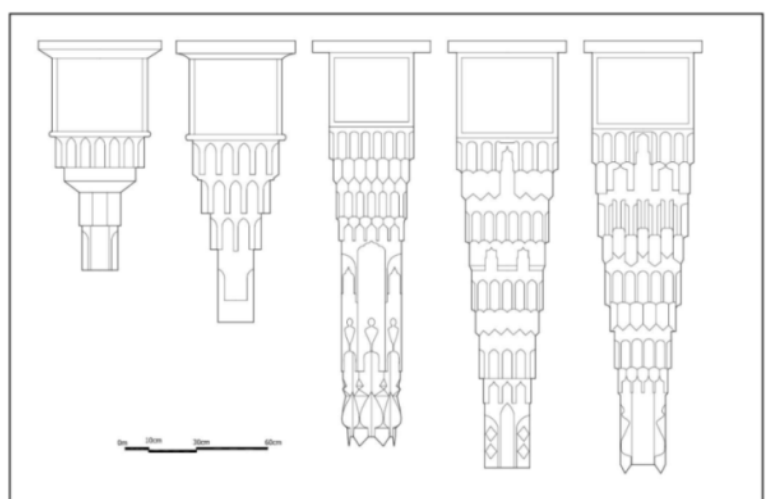

Figure 19. Column Capitals of Mehrabad mosque in Binab city (Zakiri, M.M 2009)

\subsection{Mithrava Forty Columns of Shah Abbas in Qazvin-City}

This palace has been constructed after Ottoman attack against Safavid territory when they had to displace capital city from Tabriz city to Qazvin city [13]. This palace is located in the famous gardens of Saadat Abad.This palace was the imperial palace of Shah Tahmaseb Abdulali .Mr, 2008. Octagonal plan is implemented in the formation of Forty Columns palace that includes for ivans(Figure20, 21).

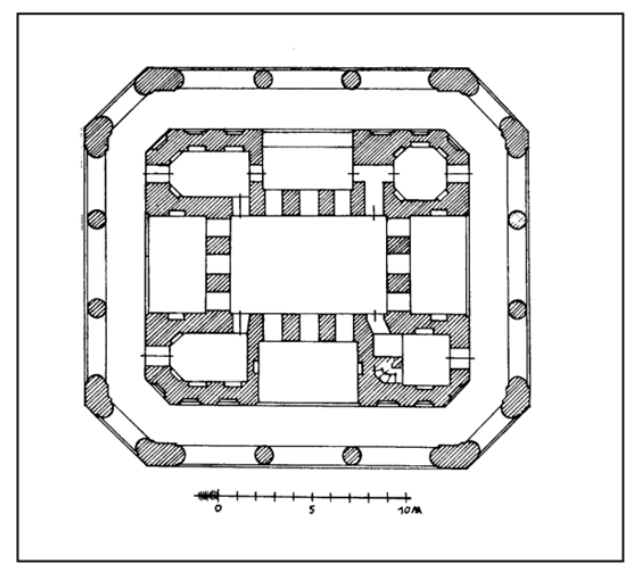

Figure 20. Ground Floor Plan of Forty Columns Palace in Qazvin City (Hillen Brand 1998)

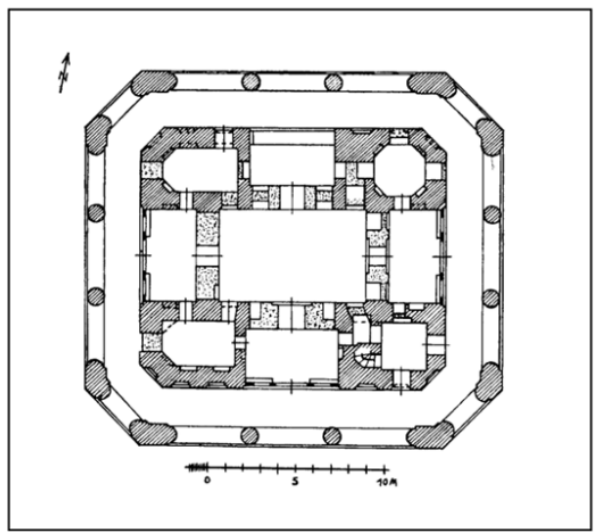

Figure 21. First Floor Plan of Forty Columns Palace in Qazvin City (Hillen Brand 1998) 
It has two floors. Fresco, plaster and tiles used in the corridors. Wooden columns and beams are implemented as structural elements (Figure 22,23). The integration of the two current architecture of the Safavid period is clearly observed. Wooden pillars and decorative painting has its roots in Sahand buildings. On the other hand, stucco and tile commonly continued according to the tradition of that era.

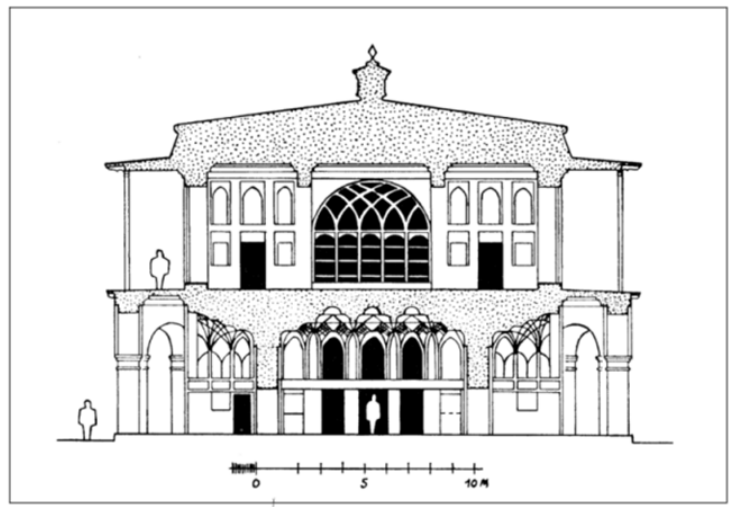

Figure 22. Section of Forty Columns Palace in Qazvin City (Kiyani M.Y 1989)

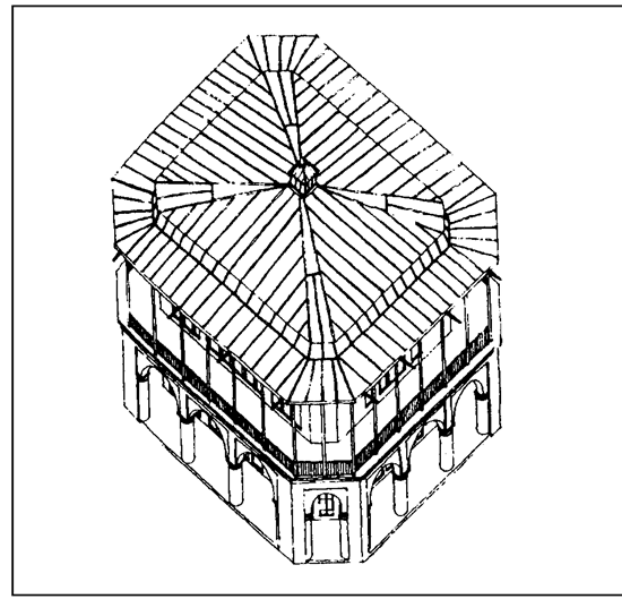

Figure 23. Perspective of Forty Columns Palace in Qazvin City (Hillen Brand 1998)

\section{Comparision of Azeri Timber Buildings}

There were some variety type of comparison methods considering Azerbaijan timber architecture according their constructional, implemented elements and floor types of presented examples. So, comparing buildings according to their variety of columns that are implemented in seraglio and arena of mosques are preferred in this research but it should not be forgotten all the plans were constructed like each other unless Forty-columns palace of Qazvin.

There is an obvious difference among buildings of Azerbaijan timber architecture. Majority of mosques are located in Maraga-city. This city includes the smallest and biggest mosque. All mentioned mosques are constructed with load-bearing walls and wooden columns.
Load-bearing walls surrounded the arenas. But, there is another type on method in this field that the Forty-columns Palace of Qazvin illustrates it as well. There are forty columns around the pavilion that surrounded load-bearing walls. These walls are located into internal part of palace opposite of mosques where load-bearing walls were located around the mosques. During the Safavid territory when they had to displace capital city from Tabriz city to Qazvin city (Abdulali .Mr, 2008). This palace is located in the famous gardens of Saadat Abad. This palace was the imperial palace of Shah Tahmaseb Abdulali .Mr, 2008. Octagonal plan is implemented in the formation of Forty Columns palace that includes for ivans (Figure20, 21).

\section{Conclusion}

This research asserted some clear results that categorized as follow;

a) There are some distinctive factors in Azerbaijan timber architecture that were presented as an architectural style during different historical eras.

b) Whereas, main material of structural elements on timber architecture is wood. So, columns and beams of Azerbaijan timber architecture are produced from local trees that were viable according to its district.

c) This style has two method to organize structures; Mosques are surrounded by load-bearing brick walls and palaces surrounded with wooden columns.

d) Wooden material has been implemented to make beams and columns. Brick used to create load-bearing walls.

e) Diameter, height and account of columns depend on the scale of buildings area.

\section{Acknowledgement}

This paper is respectfully thankful about endeavors of Arch. Mehdi Zakeri who helped during mapping process.

\section{References}

[1] Diakhonov. E. M, History of Madday, Tehran University Publication, Tehran, 5. Edition, 1981, pp13-26.

[2] Diakhonov. E. M, History of Madday, Tehran University Publication, Tehran, 5. Edition, 1981, P29.

[3] Pirnia K, Methodlogy of Iranian Architecture, Tehran university Publication, Tehran, 5. Edition, 2001, pp137.

[4] Pirnia K, 2001, Methodlogy of Iranian Architecture, Tehran university Publication, Tehran, 5. Edition P 151.

[5] Abdulali .Mr, Wooden Motifs of East Azerbaijan Mosques, Art academy of Islamic Republic of Iran, 1. Edition, Shadrang Publication, Tehran, 2008, pp18-68.

[6] Abdulali .Mr, Wooden Motifs of East Azerbaijan Mosques, Art academy of Islamic Republic of Iran, 1. Edition, Shadrang Publication, Tehran 2008, P200. 
[7] Diakhonov. E. M, History of Madday, Tehran University Publication, Tehran, 5. Edition, 1981, P42.

[8] Diakhonov. E. M, History of Madday, Tehran University Publication, Tehran, 5. Edition, 1981, P56.

[9] Abdulali .Mr, Wooden Motifs of East Azerbaijan Mosques, Art academy of Islamic Republic of Iran, 1. Edition, Shadrang Publication, Tehran 2008, P188.

[10] Abdulali .Mr, Wooden Motifs of East Azerbaijan Mosques, Art academy of Islamic Republic of Iran, 1. Edition, Shadrang Publication, Tehran 2008.

[11] Diakhonov. E. M, History of Madday, Tehran University Publication, Tehran, 5. Edition, 1981, P30.
[12] Pirnia K, Methodlogy of Iranian Architecture, Tehran university Publication, Tehran, 5. Edition 2001, P 152.

[13] Abdulali .Mr, Wooden Motifs of East Azerbaijan Mosques, Art academy of Islamic Republic of Iran, 1. Edition, Shadrang Publication, Tehran 2008, P188.

[14] Abdulali .Mr, Wooden Motifs of East Azerbaijan Mosques, Art academy of Islamic Republic of Iran, 1. Edition, Shadrang Publication, Tehran 2008, P180.

[15] Abdulali .Mr, Wooden Motifs of East Azerbaijan Mosques, Art academy of Islamic Republic of Iran, 1. Edition, Shadrang Publication, Tehran 2008, P120. 